\title{
Bone marrow transplantation in the treatment of $\alpha$-mannosidosis
}

\author{
A WILL,${ }^{*}$ A COOPER,$\dagger$ C HATTON, $\dagger$ I B SARDHARWALLA,$\dagger$ D I K EVANS,$*$ \\ AND R F STEVENS $\dagger$ \\ ${ }^{*}$ Department of Haematology and †Willink Biochemical Genetics Unit, Royal Manchester Children's \\ Hospital, Manchester
}

SUMMARY Bone marrow transplantation was performed in a patient with $\alpha$-mannosidosis. To our knowledge this is the first time such treatment has been attempted. The patient died 18 weeks after successful grafting and specimens of tissues were obtained at necropsy. Alpha-mannosidase activity in spleen and liver was just below normal (spleen $102 \mu \mathrm{mol} / \mathrm{g} / \mathrm{hour}$, control 113-330; liver $29 \mu \mathrm{mol} / \mathrm{g} / \mathrm{hour}$, control 30-131). Splenic $\alpha$-mannosidase activity was indistinguishable from the control enzyme with respect to the Michaelis constant, heat stability, and inhibition by cobalt ions, as was $86 \%$ of the liver enzyme. In brain tissue $\alpha$-mannosidase activity was $7 \%$ of controls, and less than one third had the properties of the normal enzyme. Oligosaccharides were present only in small amounts in liver and spleen, whereas they were greatly increased in brain tissue. Electron microscopic pictures of liver and spleen tissue showed normal morphology, but brain tissue showed definite vacuolation. These findings suggest that transplantation reversed the somatic changes of $\alpha$-mannosidosis but did not affect lysosomal storage within brain tissue. It is concluded that marrow transplantation may not be a suitable treatment for $\alpha$-mannosidosis.

Bone marrow transplantation has been used to correct several inborn errors of metabolism by grafting donor leucocytes which synthesise the missing enzymes. Initial results in the mucopolysaccharidoses, Hurler's syndrome (mucopolysaccharidosis I) and Sanfilippo's syndrome (mucopolysaccharidosis III) ${ }^{1}$ suggest that transplantation may be beneficial. In a recently reported case of infantile $\mathrm{G}_{\mathrm{MI}}$-gangliosidosis, ${ }^{2}$ however, regression of hepatic and splenic enlargement without improvement of cerebral symptoms was described. We report a case of a child with $\alpha$-mannosidosis (an oligosaccharidosis with many clinical similarities to Hurler's syndrome) ${ }^{3}$ who received a bone marrow transplant, and we discuss the biochemical and electron microscopic findings in tissues removed at necropsy following his death 18 weeks after grafting.

\section{Case report}

A 7 year old boy had typical clinical features of $\alpha$ mannosidosis of facial dysmorphism, dysostosis multiplex, mental deficiency, deafness, hepatosplenomegaly, and recurrent infections. ${ }^{3-6}$ The lymphocytes were vacuolated and IgG concentration was low at $3.56 \mathrm{~g} / \mathrm{l}$ (normal 6.75-18.0). There were abnormal oligosaccharide bands in the urine and leucocyte $\alpha$-mannosidase activity was grossly reduced at $2.9 \mu \mathrm{mol} / \mathrm{g} / \mathrm{hour}$ (normal $250-1100 \mu \mathrm{mol} / \mathrm{g}$ / hour). In view of the recurrent infections and hepatosplenomegaly his prognosis was poor and he was unlikely to reach adult life.$^{6}$ For this reason and because reports of bone marrow transplantation in similar inherited disorders seemed encouraging, bone marrow transplant was performed. The donor was the patient's 31 year old mother who had a one haplotype mismatch but who shared the same HLA DR type, and showed no reactivity on mixed lymphocyte culture.

Before operation the patient was given busulphan $2 \mathrm{mg} / \mathrm{kg}$ on four consecutive days followed by cyclophosphamide $60 \mathrm{mg} / \mathrm{kg} /$ day for four days. A dose of $3 \cdot 0 \times 10^{8} / \mathrm{kg}$ of cells was infused. Cyclosporin A was given as prophylaxis against graft versus host disease. Despite this he developed severe (grade III) acute graft versus host disease. Nine days after transplant he had generalised erythema, moderately severe diarrhoea, and raised liver enzyme activity with alanine transferase reaching $228 \mathrm{IU} / \mathrm{l}$. He was given large doses of methyl prednisolone $\left(1 \mathrm{~g} / \mathrm{m}^{2} /\right.$ 
day on five consecutive days) and a suspected infection was aggressively treated with netilmicin 2.5 $\mathrm{mg} / \mathrm{kg}$, azlocillin $100 \mathrm{mg} / \mathrm{kg}$, and metronidazole 10 $\mathrm{mg} / \mathrm{kg}$, each three times daily, and amphotericin 500 $\mu \mathrm{g} / \mathrm{kg}$ once a day.

Four weeks after transplantation a bone marrow aspirate showed normal cellularity but reduced numbers of megakaryocytes. Chromosomal analysis of marrow cells showed a female karyotype in all 15 cells examined. Leucocyte $\alpha$-mannosidase activity was normal at $406 \mu \mathrm{mol} / \mathrm{g} / \mathrm{hour}$ and remained so until the patient's death. Free plasma $\alpha$-mannosidase was recordable at $12 \mu \mathrm{mol} / / /$ hour (normal 20-100 $\mu \mathrm{mol} / \mathrm{l} / \mathrm{hour}$ ) and oligosacchariduria was considerably less than before grafting. The hepatosplenomegaly regressed to normal and vacuolated lymphocytes were no longer seen in the peripheral blood.

Over the next 12 weeks his progress was complicated by thrombocytopenia with recurrent bleeding and by neutropenia, lymphopenia, and hypogammaglobulinaemia, resulting in recurrent sepsis. Graft versus host disease of the skin became troublesome with a fluctuating maculopapular rash on limbs and trunk, and persistent erythema of the soles and palms. Attempts to control this by increasing doses of immunosuppressive drugs were associated with lymphopenia and a reduction in free plasma $\alpha$-mannosidase (fig 1 ). This was reversed by withdrawal of all immunosuppressive drugs without progression of his skin rash.

He died from bronchopneumonia, 18 weeks after transplantation. Necropsy was carried out within six hours of death. Candida albicans was grown from the lungs although he had been treated with

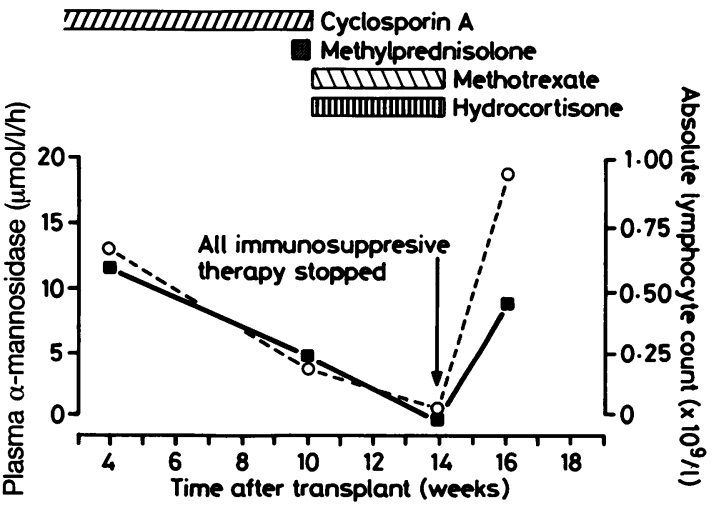

Fig 1 Relation free enzyme activity in plasma, total lymphocyte, count, and immunosuppressive treatment: O- - -Olymphocyte count; $\square$ plasma $\alpha$-mannosidase activity. intravenous amphotericin for three weeks before death. Examination of marrow, which had shown a 46XX karyotype only 10 days before death, showed normal cellularity. There was no evidence of graft versus host disease except for the skin. Apart from the lungs, the only organ showing histological abnormality was the brain which showed focal haematoxyphil masses, probably due to calcification, and focal astrocyte gliosis in the white matter.

\section{Material and methods}

\section{TISSUES}

Samples of liver, spleen, and brain tissue were obtained at necropsy. Aliquots for electron microscopic examination were placed in $3 \%$ glutaraldehyde, the remainder being snap frozen in liquid nitrogen for biochemical studies and stored at $-70^{\circ} \mathrm{C}$ until use. Samples from age matched controls were treated in an identical manner. All samples were obtained within six hours of death.

\section{OLIGOSACCHARIDE CHROMATOGRAPHY}

Tissue samples were homogenised in water using an all glass homogeniser (Gallenkamp) and protein was precipitated by adding an equal volume of $5 \%(\mathrm{w} / \mathrm{v})$ trichloroacetic acid. After centrifugation $(4000 \mathrm{~g}$ for 30 minutes) aliquots of the supernatants equivalent to $5 \mathrm{mg}$ of wet weight tissue were applied in $1 \mathrm{~cm}$ streaks to plastic backed silica gel chromatography plates (Whatman). Plates were developed, twice for $10 \mathrm{~cm}$, in butanol/acetic acid/water $(2 / 1 / 1 ; \mathrm{v} / \mathrm{v} / \mathrm{v})$. Carbohydrates were located using orcinol-sulphuric acid stain. ${ }^{7}$

\section{ENZYME STUDIES}

Tissue samples were homogenised in $0 \cdot 1 \%$ Triton $X$ 100 at $4^{\circ} \mathrm{C}$ and sonicated on ice (Rapidis Model 50 ultrasonic disintegrator), at three bursts of 10 seconds at half power with 30 second intervals between bursts. After centrifugation $(500 \mathrm{~g}$ for five minutes at $4^{\circ} \mathrm{C}$ ) the supernatants were used for enzyme assay. Alpha-mannosidase activity was determined using $2 \mathrm{mM}$ 4-methylumbelliferyl- $\alpha$-Dmannopyranoside in $0 \cdot 2 \mathrm{M}$ sodium phosphate $/ 0 \cdot 1 \mathrm{M}$ citric acid buffer, $\mathrm{pH} 4 \cdot 0$, as substrate.

The assay contained $20 \mu \mathrm{l}$ buffered substrate and sample $(0 \cdot 8-5 \cdot 5 \mathrm{~g}$ protein/l) in a final volume of 40 $\mu l$. Incubation times were $15-60$ minutes at $37^{\circ} \mathrm{C}$. Reactions were terminated by adding $2 \mathrm{ml} 0.5 \mathrm{M}$ sodium bicarbonate sodium carbonate, $\mathrm{pH} 9.5$, and the fluorescence produced was measured in an Aminco Bowman fluorocolorimeter (excitation 360 $\mathrm{nm}$, emission $440 \mathrm{~nm}$ ). Specific activities were calculated as $\mu \mathrm{mol} / \mathrm{g}$ protein/hour. Protein concentrations were determined by the method of Lowry. ${ }^{8}$ 
The effect of cobalt ions was investigated by including $0-10 \mathrm{mM}$ cobaltous sulphate in the standard assay. ${ }^{6}$ Michaelis constant values were determined by Hanes plots using final substrate concentrations of 0.5-10 mM. For thermal stability studies, samples were diluted $9 / 1(\mathrm{v} / \mathrm{v})$ with $0 \cdot 2 \mathrm{M}$ sodium phosphate/ $0 \cdot 1 \mathrm{M}$ citric acid buffer, $\mathrm{pH} 6 \cdot 0$, heated at $60^{\circ} \mathrm{C}$ for up to 60 minutes, and cooled on ice before assay.

\section{Results}

Thin layer chromatography of oligosaccharides extracted from tissues showed only slight increases in the liver and spleen of the patient compared with those of controls, but severely abnormal storage of oligosaccharides had persisted in the patient's brain (fig 2).

The table shows that almost normal amounts of acid $\alpha$-mannosidase activity were present in the liver and spleen, but the activity in the brain was only $7 \%$ of the mean control value. Acid $\alpha$-mannosidase from the patient's spleen was stable to heating at $60^{\circ} \mathrm{C}$, as was $86 \%$ of the activity in liver, but about $70 \%$ of the residual activity in the brain was heat labile (fig 3).

In all control tissues acid $\alpha$-mannosidase activity was inhibited by cobalt ions. In the patient's tissues, activity in the spleen showed identical inhibition while that in the liver was only slightly inhibited and that in the brain showed about a threefold stimulation (fig 4). When these experiments were repeated after preincubating the tissue homogenates at $60^{\circ} \mathrm{C}$ for one, hour, no difference in the effect of cobalt was found between the control and the patient's acid $\alpha$-mannosidase activity in any tissue (fig 5 ).

Apparent Michaelis constant values determined by Hanes plots were measured for control enzyme and in patient's tissues both before and after heat inactivation at $60^{\circ} \mathrm{C}$ (table). The apparent Michaelis

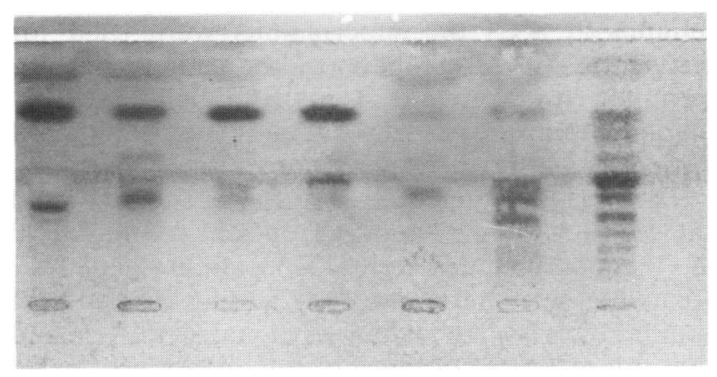

Fig 2 Oligosaccharide chromatography of necropsy tissues (left to right) normal spleen; patient's spleen; normal liver; patient's liver; normal brain; patient's brain; and urine from patient before transplant.

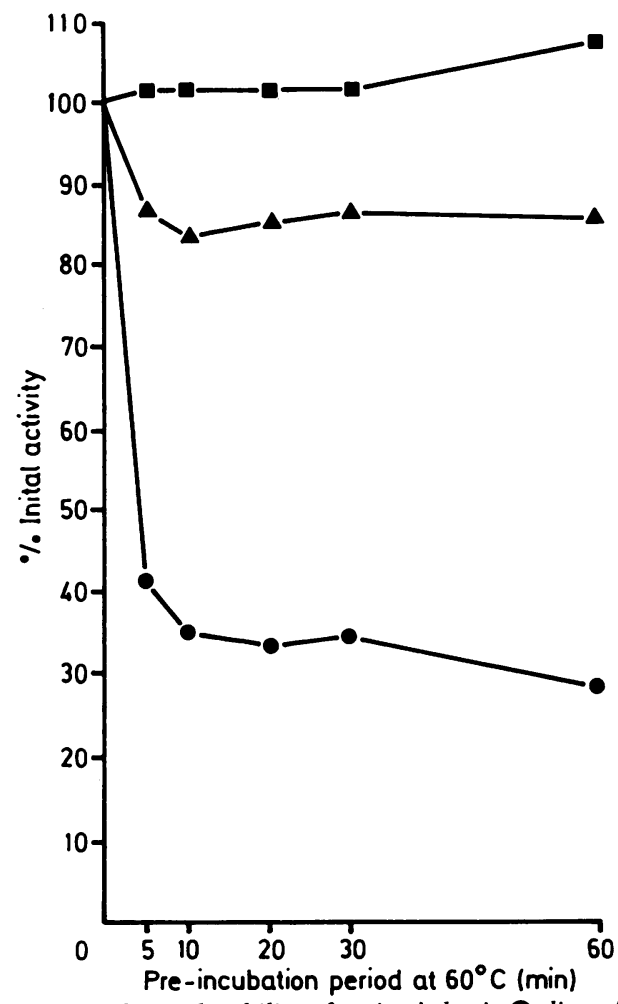

Fig 3 Thermal stability of patient's brain , liver $\mathbf{\Delta}$, and spleen $\mathbf{\alpha}$-mannosidase.

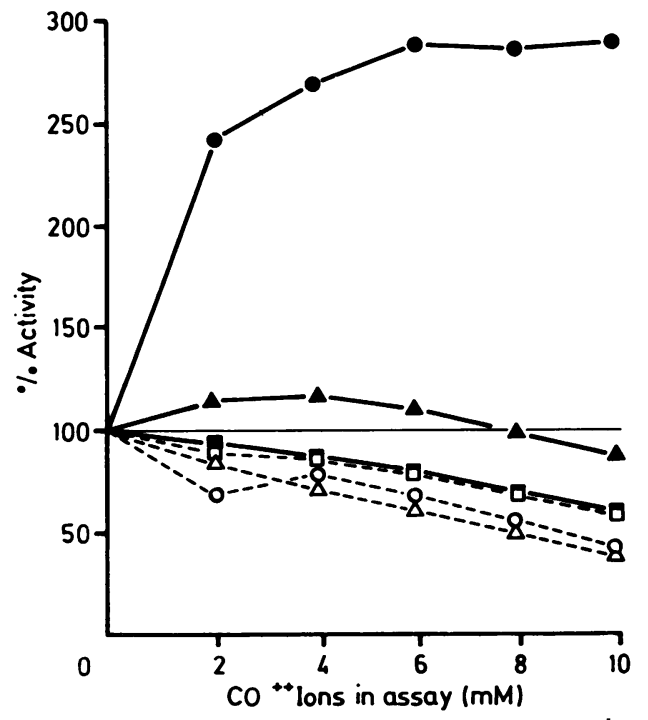

Fig 4 Effect of cobalt ions on patient and control $---\alpha$-mannosidase activity in brain $\bigcirc$, liver $\mathbf{\Delta}$, and spleen $\mathbf{\square}$. 


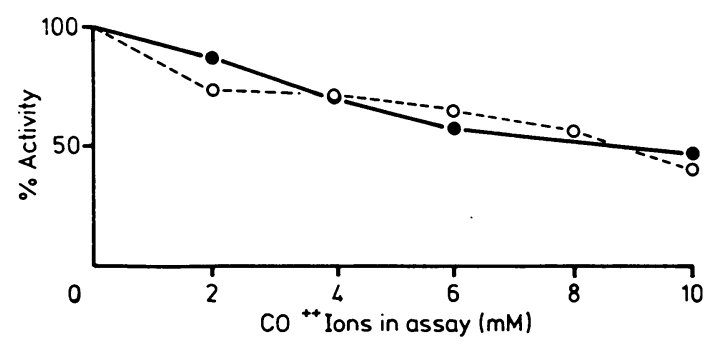

Fig 5 Effect of cobalt ions on patient's brain $\bigcirc$ and liver $\bigcirc$ $\alpha$-mannosidase activity after preincubation at $60^{\circ} \mathrm{C}$ for one hour.

constant of the enzyme in the patient's splenic tissue was identical with control values, but the patient's liver and brain tissues before heat inactivation produced non-linear plots. Preincubating the tissues at $60^{\circ} \mathrm{C}$ produced values for the enzyme in patient's liver and brain identical with those from controls (table). Electron microscopy of liver (fig 6a)
Table Alpha-mannosidase: specific activity and some properties of necropsy tissue

\begin{tabular}{|c|c|c|c|}
\hline & 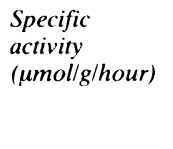 & $\begin{array}{l}\text { Michaelis } \\
\text { constant } \\
(\mathrm{mM}) \\
\text { before } \\
\text { heating }\end{array}$ & $\begin{array}{l}\text { Michaelis } \\
\text { constant } \\
\text { (mM) } \\
\text { after } \\
\text { heating* }\end{array}$ \\
\hline \multicolumn{4}{|l|}{ Spleen: } \\
\hline Patient & 102 & $1 \cdot 0$ & $1 \cdot 0$ \\
\hline \multicolumn{4}{|l|}{ Controls $(n=3)$} \\
\hline Range & $\begin{array}{l}113-330 \\
(\text { mean 194.76) }\end{array}$ & $0 \cdot 9-1 \cdot 0$ & $0 \cdot 9-1 \cdot 0$ \\
\hline \multicolumn{4}{|l|}{ Liver: } \\
\hline Patient & 29 & Non-linear & $1 \cdot 0$ \\
\hline \multicolumn{4}{|l|}{ Controls $(n=3)$} \\
\hline Range & $\begin{array}{l}30-131 \\
(\text { mean 53.6) }\end{array}$ & $0 \cdot 8-1 \cdot 0$ & $0 \cdot 8-1 \cdot 0$ \\
\hline \multicolumn{4}{|l|}{ Brain: } \\
\hline Patient & $3 \cdot 1$ & Non-linear & $1 \cdot 0$ \\
\hline \multicolumn{4}{|l|}{ Controls $(n=3)$} \\
\hline Range & $\begin{array}{l}21-65 \\
\text { (mean 43.7) }\end{array}$ & $0 \cdot 9-1 \cdot 0$ & $0 \cdot 7-0 \cdot 9$ \\
\hline
\end{tabular}

${ }^{*}$ For 60 minutes at $60^{\circ} \mathrm{C}$.

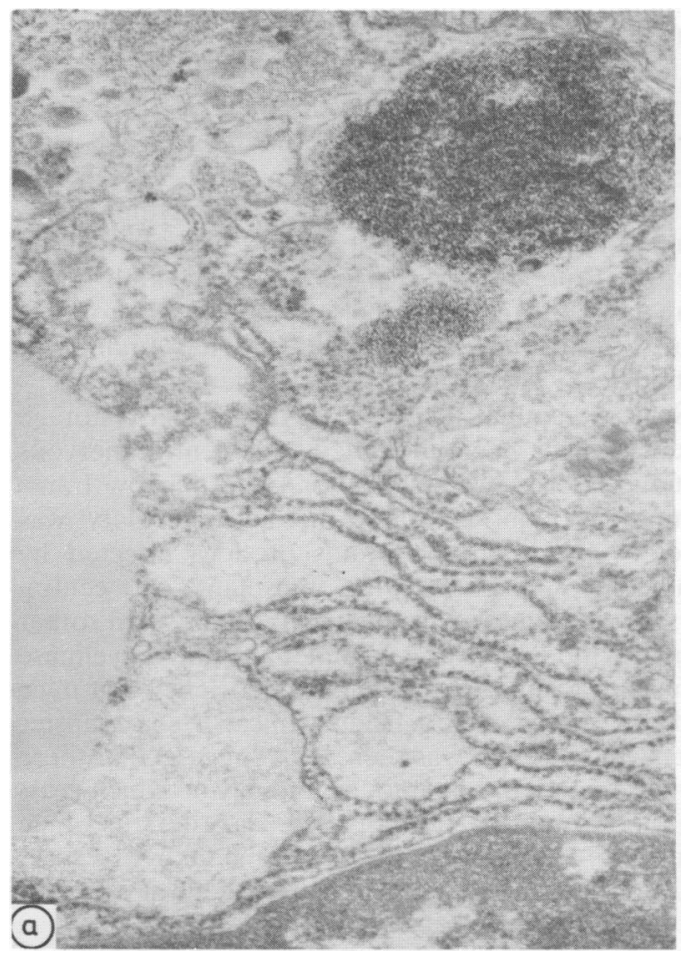

Fig 6a Electron micrograph of liver 18 weeks after transplant showing normal morphology.

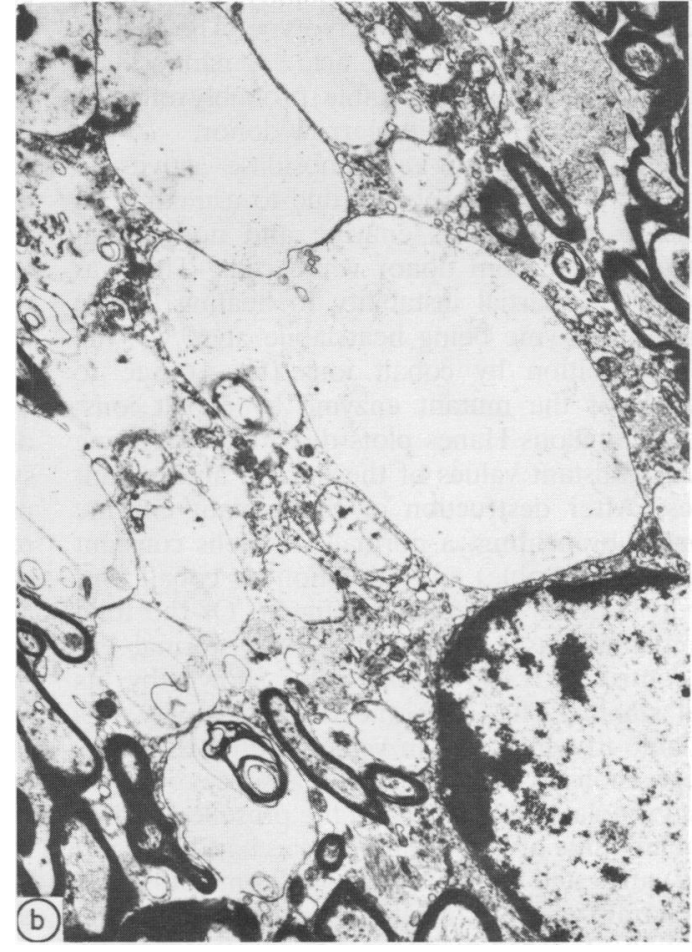

Fig 6b Electron micrograph of brain 18 weeks after transplant showing pronounced cytoplasmic vacuolation. 
showed normal morphology in contrast to the pronounced cytoplasmic vacuolation reported in untreated patients with $\alpha$-mannosidosis. ${ }^{9}$ The brain, however, showed extensive vacuolation of the cytoplasm (fig 6b), suggesting little or no degradation of the mannose rich oligosaccharides stored within its lysosomes.

\section{Discussion}

Acid $\alpha$-mannosidase activity has three properties which allow normal and mutant $\alpha$-mannosidosis enzymes to be distinguished. Normal enzyme is heat stable at $60^{\circ} \mathrm{C}$, while mutant enzyme is rapidly inactivated at this temperature. ${ }^{10}$ Cobalt ions inhibit normal acid $\alpha$-mannosidase activity but stimulate residual mutant enzyme. ${ }^{6}$ The mutant acid $\alpha$ mannosidase activity has a much higher Michaelis constant than normal enzyme. ${ }^{6}$

Acid $\alpha$-mannosidase activity of the patient's spleen was indistinguishable from the control enzyme with respect to heat stability (fig 3 ), inhibition by cobalt ions (fig 4), and Michaelis constant (table). This is to be expected because of the concentration of white cells in this organ. The white cell population was shown consistently to originate from the donor by its female karyotype. The slightly reduced specific activity of acid $\alpha$-mannosidase compared with control values (table) probably reflected the carrier state of the bone marrow donor.

The near normal acid $\alpha$-mannosidase activity in the patient's liver was probably due to a mixture of abnormal $\alpha$-mannosidosis enzyme and normal enzyme transferred from donor white cells. This was shown by: the partial instability to heating (fig 3) (the mutant enzyme being heat labile at $60^{\circ} \mathrm{C}$ ); the reduced inhibition by cobalt ions (fig 4) due to stimulation of the mutant enzyme by cobalt ions; and the anomalous Hanes plots due to the differing Michaelis constant values of the normal and mutant enzymes. After destruction of the mutant enzyme component by heating, a normal Michaelis constant value of $1 \mathrm{mM}$ (table) and inhibition by cobalt ions similar to controls were shown (fig 5). Of the total acid $\alpha$-mannosidase activity, $86 \%$ was normal enzyme contributed by donor cells, shown by its thermal stability (fig 3). Some of this activity was attributable to white cells in vessels within the liver. The regression of hepatomegaly, absence of cytoplasmic vacuolation (fig 6a), and the presence of only residual amounts of abnormal oligosaccharides (fig 2) strongly suggested that normal acid $\alpha$-mannosidase had been transferred to hepatic lysosomes, facilitating degradation of stored mannose rich oligosaccharides within the lysosomes. Similar clinical regression of somatic abnormalities has been reported in other lysosomal storage diseases after bone marrow transplantation. ${ }^{12}$

In patients with $\alpha$-mannosidosis the brain may contain up to $21 \%$ of the mean control $\alpha$ mannosidase activity. ${ }^{3}$ In our patient the enzyme activity in the brain was $7 \%$ of the mean control value (table). Less than one third had the properties of normal enzyme with respect to heat stability (fig 3 ), inhibition by cobalt ions (figs 4 and 5), and Michaelis constant (table). It is not possible to say whether the small amount of normal enzyme was already present before bone marrow transplantation, but no residual activity with the properties of normal enzyme was seen in cultured skin fibroblasts. Thus the normal acid $\alpha$-mannosidase activity of the patient's brain, possibly contributed by donor cells, was only about $2 \%$ of the mean control values. At least part of this residual activity must have been due to white cells within vessels in the brain. Indeed, the persistence of cytoplasmic vacuolation (fig 6b) and grossly abnormal oligosaccharide storage within brain tissue (fig 2) suggest that little if any normal acid $\alpha$-mannosidase had crossed the blood brain barrier and entered lysosomes within the brain cells.

These results correlate well with the case of a chimeric Angus calf with $\alpha$-mannosidosis. ${ }^{11}$ The calf, which exhibited male phenotype, obtained a natural transplant of lymphocytes from its normal female twin during fetal development as a result of placental fusion. Chromosome analysis of 200 lymphocytes showed two cell populations, $77 \% 60 \mathrm{XX}$ and $23 \% 60 \mathrm{XY}$, indicating $77 \%$ of lymphocytes were 'donor' in origin. At necropsy, performed at the age of 14 months, liver, pancreas, and lymph nodes were less affected than those of a control group of animals with $\alpha$-mannosidosis, but the brain was histologically similar to that of affected animals.

Several animal models of lysosomal storage diseases have been identified and central nervous system changes evaluated after bone marrow transplantation. Considerable $\alpha$-fucosidase activity was recently shown in the brains of dogs affected by canine fucosidosis following transplant, and central nervous system lesions were reversed. ${ }^{12}$ In other animal models-for example, sphingomyelinase deficiency ${ }^{13}$ and $\beta$-glucuronidase deficiency ${ }^{14}$ of mice and aryl sulphatase $B$ deficiency of cats ${ }^{15}$-no transfer of enzyme to brain was seen. This suggests that there are differences in the amounts of enzyme which cross the blood brain barrier. In those disorders in which transfer of minute amounts of enzyme takes place it is doubtful whether any functionally beneficial effect on the brain can be expected.

In the one reported case of bone marrow transplantation in a patient with metachromatic leucodystrophy the white cells in the cerebrospinal fluid 
were shown to originate from the donor's grafted bone marrow. ${ }^{16}$ This finding should be interpreted with caution. As the bone marrow is the main source of white cells in the cerebrospinal fluid, their presence in that fluid is to be expected, but it would be misleading to conclude that the enzyme has actually crossed the blood brain barrier and entered the brain tissue. A progress report on this patient's neurological state and mental development is required.

It has been argued that bone marrow transplantation should be performed as soon as possible after birth if maximum benefit is to be obtained, ${ }^{17}$ but this depends on the amount of enzyme transferred into the brain. Although our patient did not have a transplant until the age of 6 years, the quantity of normal $\alpha$-mannosidase transferred was extremely small. Whether more prolonged survival of the present case would have changed the biochemical findings in the brain and produced any functional benefit is open to speculation. We think that this is unlikely as clinical, biochemical, and electron microscopic changes in the liver and spleen were extremely rapid. From our results we conclude that bone marrow transplantation may not affect the neurological course of patients with $\alpha$-mannosidosis. It is also possible that other lysosomal storage disease affecting the central nervous system (such as some mucopolysaccharidoses) may not respond to this form of treatment. ${ }^{12}$ It is therefore important that if such patients die after bone marrow transplantation every effort should be made to undertake the type of studies we have described, so that the results of treatment can be quantitated precisely.

We thank members of the nursing staff of the bone marrow unit for their devoted attention to this patient. We also thank Professor B Marsden for his help in interpreting the electron micrographs.

\section{References}

${ }^{1}$ Hobbs JR. Correction of 34 genetic diseases by displacement bone marrow transplantation. Plasma Therapy and Transfusion Technology 1985;6:221-46.

${ }^{2}$ Shaw PJ, Hobbs JR, Cooper A, Lealman GT. G $\mathrm{MI}^{-}$ gangliosidosis: failure to halt neurological regression by bone marrow transplantation. Bone Marrow Transplant 1986;1 (suppl 1):339.

${ }^{3}$ Ockerman P-A. A generalised storage disorder resembling Hurler's syndrome. Lancet 1967;ii:239-41.

${ }^{4}$ Autio S, Norden NE, Ockerman P-A, Riekkinen P, Rapola J, Louhimo T. Mannosidosis: clinical, fine-structural and biochemical findings in three cases. Acta Paediatr Scand 1973;62: 555-65.

5 Aylsworth AS, Taylor HA, Stuart $\mathrm{CH}$, Thomas GH. Mannosidosis: phenotype of a severely affected child and characterisation of $\alpha$-mannosidase activity in cultured fibroblasts from the patient and his parents. J Pediatr 1976;88:814-8.

6 Desnick RJ, Sharp HL, Grabowski GA, et al. Mannosidosis: clinical, morphologic, immunologic and biochemical studies. Pediatr Res 1976;10:985-6.

7 Matsuura F, Nunez HA, Grabowski GA, Sweeley CC. Structural studies of urinary oligosaccharides from patients with $\alpha$ mannosidosis. Arch Biochem Biophys 1981;207:337-52.

${ }^{8}$ Lowry OH, Rosebrough NJ, Farr AL, Randall RJ. Protein measurement with the folin phenol reagent. J Biol Chem 1951;193:265-75.

${ }^{9}$ Gordon BA, Carson R, Daria Haust M. Unusual clinical and ultrastructural features in a boy with biochemically typical mannosidosis. Acta Paediatr Scand 1980;69:787-92.

10 Taylor HA, Thomas GH, Aylsworth A, Stevenson RE, Reynolds LW. Mannosidosis: deficiency of a specific $\alpha$ mannosidase component in cultured skin fibroblasts. Clin Chim Acta 1975;59:93-9.

"Jolly RD, Thompson RG, Murphy CE, Manktelow BW, Bruere AN, Winchester BG. Enzyme replacement therapy-an experiment of nature in a chimeric mannosidosis calf. Pediatric Res 1976;10:219-24.

12 Taylor RM, Farrow BRH, Stewart GJ, Healy PJ. Enzyme replacement in nervous tissue after allogenic bone-marrow transplantation for fucosidosis in dogs. Lancet 1986;ii:772-4.

13 Sakiyama T, Tsuda M, Owada M, Joh K, Mujawaki S, Kitagawa $\mathrm{T}$. Bone marrow transplantation for Niemann-Pick mice. Biochem Biophys Res Commun 1983;113:605-10.

${ }^{14}$ Hoogerbrugge PM, Poorthuis BJHM, Wagemaker G, van Bekkum DW, Vossen JMJJ, Dooren LJ. Bone marrow transplantation in $\beta$-glucuronidase deficient $\mathrm{C} 3 \mathrm{H}$ mice. Exp Hematol 1985;13:430.

15 Wenger DA, Gasper PW, Thrall MA, Dial SM, Lecouteur RA, Hoover EA. Bone marrow transplantation in the feline model of aryl sulphatase B deficiency. Birth Defects 1986;22:177-86.

16 Bayever E, Ladisch S, Philippart M, et al. Bone marrow transplantation for metachromatic leucodystrophy. Lancet 1985; ii:471-3.

17 Editorial. Bone marrow transplant for neurovisceral storage diseases. Lancet 1986;ii:788-9.

Correspondence to Dr IB Sardharwalla, Willink Biochemical Genetics Unit, Royal Manchester Children's Hospital, Pendlebury, Manchester M27 1HA.

Received 18 May 1987 